\title{
Parental Beliefs and Perceptions of the Role of Middle Schools in Student Tobacco Use Prevention Activities in Juárez, Mexico
}

\author{
Yelena Bird ${ }^{1}$, John Moraros ${ }^{1}$, Robert W. Buckingham ${ }^{1}$, Hugo Staines-Orozco ${ }^{2}$, \\ and Jeffrey E. Brandon ${ }^{1}$ \\ ${ }^{1}$ New Mexico State University \\ ${ }^{2}$ Universidad Autonoma de Ciudad Juárez
}

\begin{abstract}
The purpose of this study was to examine parental beliefs and perceptions of the role that schools should play in implementing smoking prevention activities for their children in Juárez, Mexico. The parents were of sixth grade students from six randomly selected middle schools. Schools were classified by school setting and socioeconomic status. A total of 506 surveys were sent to the homes of the parents and $77 \%$ $(\mathrm{N}=390)$ responded. The majority of the parents $(88 \%)$ were supportive of smoking prevention activities. Furthermore, mothers were significantly more likely than fathers to agree that the school had an important role to play in smoking prevention activities $(p<0.01)$. Parents of students in the low SES category regardless of school setting were significantly more likely to support the implementation of smoking prevention activities than parents of students who attended either a middle or high SES school setting $(p<0.01)$. However, even though $79 \%$ of parent respondents believed their child's school should get parental input about what should be taught in tobacco prevention programs, only $62 \%$ felt that such activities should include homework and projects involving families. These results provide further evidence that if school-based adolescent tobacco prevention programs are to be successful, public health initiatives need to do a much better job not only soliciting and receiving parental input with regard to proposed anti-tobacco curricula but also in convincing parents of the importance of becoming active participants in the process.
\end{abstract}

(C) 2006 Californian Journal of Health Promotion. All rights reserved.

Keywords: parent beliefs and perceptions, role of schools, adolescent tobacco use, tobacco prevention activities

Worldwide, tobacco use is progressively becoming an increasing threat to the health of adolescent populations. The age of tobacco smoking initiation is on a continual decline, with an estimated $60 \%$ of adolescents beginning to smoke by the age of 13 and $90 \%$ by the age of 20 (Glynn \& Manley, 1992). In Mexico, it has been estimated that the prevalence of smoking among adolescents increased from $7.7 \%$ in 1988 (MNAS, 1988) to $11.6 \%$ by 1998 (MNAS, 1998). This represents a $51 \%$ increase, in spite of the fact that the General Health Law enacted in 1984, strictly prohibits the sale of cigarettes to minors. Furthermore, the 1998 Mexican National Addiction Survey (MNAS) also reported a dramatic increase in tobacco use in smokers between the ages of 12 and 17, especially among the ranks of elementary school $(20 \%)$ and middle school students (43\%).

Research has indicated that the younger the age of smoking initiation, the more likely it is for one to become strongly addicted to nicotine and consequently, the less likely it is to quit smoking (Flint, Yamada, \& Novotny, 1998; U.S. Department of Health and Human Services [USDHHS], 1988). Evidence of nicotine dependence has been documented in 12- to 13year-olds even after only a few days or weeks of light smoking (DiFranza, Rigotti, \& McNeill, 2000).

It is estimated that about half of adolescents who continue to smoke will die from smoking-related illnesses (Centers for Disease Control \& 
Prevention [CDC], 1996). This will result in premature loss of life for over 5 million youths (Peto, Lopez, Boreham, Than, \& Heath, 1994). For this reason, it is very important that smoking education begins at a young age (Everett, Warren, Sharpe, Kann, Husten, \& Crossett, 1999). School health programs have been reported to be an effective means of preventing tobacco use among adolescents (Glynn, 1989; National Cancer Institute [NCI], 1990).

Unfortunately, in Mexico there are few if any school based tobacco prevention programs. Even in the United States, the School Health Policies and Programs Study (SHPPS, 2000) indicated that less than $20 \%$ of the states and less than $60 \%$ of the school districts required schools to offer tobacco prevention services (CDC, 2001). In general, Mexico does not require school districts or schools to provide tobacco use prevention services to students (Valdes-Salgado, Micher, Hernandez, Hernandez, \& Hernandez- Avila, 2002). However, Mexico does have a tobacco free school environment policy, which includes prohibiting cigarette smoking, cigar smoking, and smokeless tobacco use among students, faculty, staff, and visitors on school grounds. Unfortunately, the law is rarely, if ever enforced.

A recent study in Juárez, Mexico determined that $26.1 \%$ of sixth grade students reported being current smokers with the percentages being rather equivalent among boys (54\%) and girls (46\%). Of these students, slightly more than half, $55.3 \%$ indicated that they had initiated smoking at or before the age of 10 years (Bird, Moraros, Olsen, Forster-Cox, Staines-Orozco, 2006). The authors concluded that if public health interventions to prevent initiation and to assist in the cessation of smoking among adolescents as well as to reduce their environmental tobacco smoke (ETS) exposure both at home and in public places are to be successful, they would need to target young students (i.e. elementary and middle school levels) and especially those attending school in a low SES settings.

However, if effective smoking prevention programs are going to be developed and implemented within schools, it is important to understand the parents' beliefs and perceptions of the role that schools should play in such efforts. A comprehensive review of the literature found only one study pertaining to parental perceptions of the role that schools should play in their children's tobacco use practices. Clark and colleagues (1999) found that many Caucasian parents acknowledged tobacco control and prevention activities among teens to be an appropriate role for schools to play, while African-American parents believed schools should only reinforce the teaching of the parents concerning tobacco use.

Parental attitudes toward their children's smoking have been shown to be strongly related to adolescent smoking. It has been demonstrated that parental indifference to their child's smoking habits increased the likelihood of smoking in 13-14 year olds (Dusenbury et al., 1992; Newman, \& Ward, 1989; Sargent \& Dalton, 2001). Therefore, it is evident that parental perceptions of tobacco issues in schools are important because if coordinated, schoolbased, tobacco prevention efforts are to be successful, parents need to play an integral role in that endeavor. Thus, it is useful for schools to know what parents think about this issue before they introduce or implement any curricular changes.

Therefore, the purpose of this study was to examine parental beliefs and perceptions of the role that middle schools should play in smoking prevention activities for their children in Juárez, Mexico. More specifically, the present study examined the hypothesis of whether there is a difference in the level of support for smoking prevention activities among the parents of sixth grade students in Juárez, Mexico based on gender (male vs. female), school setting (public vs. private), and SES (low, middle, and high).

\section{Methods}

\section{Setting}

The present study was conducted in Juárez, Mexico. Juárez is a growing industrial city in the Mexican state of Chihuahua. It stands on the Rio Grande (Río Bravo del Norte), across the U.S. border from its sister cities of El Paso, Texas 
and Las Cruces, New Mexico. The three cities form a bi-national metropolitan area of approximately 2.5 million people, divided by the Rio Grande, making it the largest binational metropolitan area on the US-Mexico border. It is the major port of entry and transportation center of north central Mexico and the fifth largest city in the country with a population of approximately 1.4 million inhabitants, $38 \%$ of whom are reported to be 18 years old and younger (INEGI, 2000).

\section{Participants}

A cross sectional study was conducted to examine the parental perceptions of the role that schools should play in smoking prevention activities for their sixth grade children in Juárez, Mexico. A list of middle schools within the city limits of Juárez was obtained from the Secretaria de Educacion (Ministry of Education). Each of the middle schools was placed in one of two settings: public school or private school. Socioeconomic economic status (SES) information was obtained from the Secretaria de Educacion of Juárez, Mexico. Based on this information, all middle schools were stratified by SES (average annual household income) to low, middle, and high $(<10,000,10,001-25,000$, and $>25,001$ Mexican pesos, respectively) [ $\$ 1$ US dollar $=11$ Mexican pesos]. Within each school setting and SES category, one school was randomly selected.

School principals from the six randomly selected middle schools were contacted using a letter prepared by the investigators through the Universidad Autonoma de Juárez (UACJ), School of Medicine. The letter asked the principals of each respective middle school to grant permission to the investigators to access student homes by assisting in sending the surveys to the parents of their sixth grade students. All six principals agreed to participate. All study procedures and instruments were reviewed and approved by the Institutional Review Boards at New Mexico State University (NMSU) and UACJ. The parents of all enrolled sixth grade students in each one of the six schools $(\mathrm{N}=506)$ were eligible to participate. No monetary or non-monetary incentive was offered to the participating schools or parents.

\section{Instrument}

The instrument used in this study was mainly based on the Guidelines for School Health Programs to Prevent Tobacco Use and Addiction developed by the Centers for Disease Control and Prevention (CDC, 1994). A 24-item closed format survey instrument was used regarding parental beliefs and perceptions about the schools' role concerning smoking prevention programs for their children.

\section{Survey Validity \& Reliability}

Both face and content validity of the survey was established by having the English version of instrument translated to Spanish and then backtranslated to English. A panel of experts in Mexico reviewed the Spanish version of the instrument. The panel consisted of three fulltime faculty members of UACJ who were experts in public health, medicine, tobacco, pediatrics, and education. After expert review, minor changes were made to the instrument to ensure that the face and language validity of the survey were adequate and that it used common and simple Spanish words that could be easily understood by the parents of the sixth grade students.

Conducting a pilot test assessed the reliability of the survey instrument. The pilot study group consisted of two samples of convenience comprised of parents $(\mathrm{N}=24)$ of sixth grade students from two middle schools in Juárez, one public, middle class school and one private, middle class school. Neither of these schools had been selected for inclusion in the main study. Analysis of the pilot data demonstrated an internal reliability of $.88 \%$.

\section{Procedure}

The survey packet to the parents was prepared with the assistance of UACJ and consisted of a brief cover letter assuring confidentiality and a copy of the two-page, 24-question survey. Distribution of the survey packet took place during the last class period and students were instructed to present it to their parents upon arrival at home. Parents were instructed to complete the survey, place it in the accompanying brown manila envelope, seal it, 
and put it in their child's schoolbag so that they may submit it to their teacher during the first class period the very next morning.

One week after the initial request, a second cover letter and another copy of the survey were sent to the homes of students whose parents had not responded. Two-weeks after the second request, a colored flyer reminder and another copy of the survey were sent home in the school bag of the students whose parents had not responded. These non-respondent parents were once again instructed to complete the survey and place it in their child's school bag, who would then return it to their teachers the following day (King, Pealer, \& Bernard, 2001). By the end of the month long process, the researchers were able to secure a response rate of $77 \%(\mathrm{~N}=390)$.

\section{Data Analysis}

All data analyses were conducted using the SPSS 12.0 statistical software package. The level of significance for all statistical tests was set at the 0.05 level. Frequencies, means, and standard deviations were used to describe the participants and their responses on the survey instrument. Chi-square analysis was calculated to determine relationships between nonparametric independent and dependent variables tests. T-tests were calculated to determine relationships between dichotomous independent and parametric dependent variables.

Analysis of variance tests (ANOVAs) and Multivariate analysis of variance tests (MANOVAs) were calculated to determine the relationships between categorical independent and individual or multiple parametric dependent variables respectively.

For all significant ANOVAs and MANOVAs, post-hoc Bonferroni t-tests were conducted to determine which levels of the independent variables were significantly different across such variables as parental gender (male vs. female), school setting (public vs. private), and SES (low, middle, and high).

\section{Results}

\section{Characteristics}

Demographic and Background

The majority of responding parents were female (68\%); the mothers/step-mothers of the children (45\%); between the ages of 30-49 (74\%); were nonsmokers that had never smoked (53\%); had not graduated from high school (54\%); and their children attended a public middle school (55\%) (Appendix A).

\section{Parental Beliefs and Perceptions}

The survey contained ten items that measured parental beliefs and perceptions of the role that schools in Juárez, Mexico should play in tobacco prevention activities (Appendix B). On eight of the items, there were over $80 \%$ of parents who agreed with the statement. There were only two items where approximately $60 \%$ of the parents agreed with the statement. These two items pertained to whether parents believed that their child's school should train student leaders to help teachers' present tobacco prevention lessons $(62 \%)$ and on whether their child's school should give homework and projects about tobacco that involved families (61\%) (Appendix B).

\section{Smoking Prevention Activities}

The majority of parents (88\%) were supportive of smoking prevention activities for their sixth grade children. Overall, there was a statistically significant difference by parental gender regarding their support of school sponsored smoking prevention activities for their children $(\mathrm{F}=4.820, \mathrm{df}=12, \mathrm{p}=0.001)$. On all prevention items, females had stronger agreement than males. Similarly, there was a statistically significant difference by the respondents' relationship to the child and their support of smoking prevention activities for their children $(\mathrm{F}=2.354, \quad \mathrm{df}=21, \quad \mathrm{p}=0.001) . \quad$ Statistically significant differences were found between mothers/step-mothers when compared to fathers/step-fathers that schools should: teach students why young people start to use tobacco ( $84 \%$ vs. $77 \%$ ); teach about the harmful social effects of tobacco use ( $88 \%$ vs. $82 \%)$; train teachers to teach tobacco prevention lessons ( $83 \%$ vs. $74 \%$ ); and train student leaders to help 
teachers present tobacco prevention lessons $(65 \%$ vs. $56 \%)$.

Additionally, statistically significant differences were found for parental support of smoking prevention activities for their children when stratified by school setting (public vs. private) $\left(\chi^{2}=14.67, \mathrm{df}=5, \mathrm{p}=0.003\right)$ and $\operatorname{SES}\left(\chi^{2}=22.16\right.$, $\mathrm{df}=13, \mathrm{p}=0.004)$. There was a statistically significant difference in parental support on five of the 10 smoking prevention activities items for the children who attended a low SES $(\mathrm{F}=1.964$, $\mathrm{df}=24, \mathrm{p}=0.01)$, public school setting $(\mathrm{F}=2.166$, $\mathrm{df}=22, \mathrm{p}=0.03$ ). Low SES parents of sixth grade students were significantly more likely to support prevention items concerning teaching students the harmful physical effects of tobacco use $(\mathrm{p}=0.01)$; teaching students how to avoid tobacco use $(\mathrm{p}=0.02)$; providing classroom lessons to help students refuse pro tobacco messages and advertisements $(\mathrm{p}=0.02)$; and training teachers to teach tobacco prevention lessons $(\mathrm{p}=0.01)$, when compared to their middle and high SES counterparts. Remarkably, a significant difference was discovered concerning the prevention item of whether schools should give homework and projects about tobacco that involve families, with low SES parents of sixth grade students being least likely to support such efforts $(\mathrm{p}=0.01)$ (Appendix B).

\section{Multiple Regression Analysis}

We examined the associations between the outcome variables (i.e., parental support of school sponsored smoking prevention activities for their sixth-grade children) and the sociodemographic characteristics of the participant parents (gender, school setting, and SES) by using a multiple logistic regression analysis model, as shown in Table 1. The outcome measures are presented individually and the sociodemographic characteristics were treated as independent variables in the model. Odds ratios are shown in relation to a reference category for each variable. The regression results confirm the overriding influence of SES on half of the outcome variables. In fact, statistical significance in the multivariate framework was even greater after controlling for the effects of all other variables, suggesting that SES has its own independent effect on parental support of school sponsored smoking prevention activities for their sixth-grade children in Juárez, Mexico (Appendix C).

\section{Discussion}

This study presents some important public health implications for tobacco education in middle school settings. First, the majority of parents were supportive of smoking prevention activities for their children. The research findings of the present study show that parents in general and especially those of children attending school in a low SES, public school setting are in support of middle schools providing tobacco prevention activities for their sixth-grade children.

Therefore, school districts and superintendents in Juárez, Mexico need to find ways to make these tobacco prevention activities part of the educational curriculum offered in middle schools. Superintendents, school principals, and teachers need to reach out to appropriate community organizations such as Consejo Nacional Contra las Adicciones, Sociedad Mexicana de Cardiologia, and Asociación Mexicana de Lucha contra el Cáncer (AMLCC), so that they may collaborate in an effort to provide much needed and useful tobacco prevention services to adolescents. If the school districts and the local community organizations pool their limited resources and work together, then effective, affordable, and readily accessible tobacco prevention programs will become available to adolescent students.

Second, $79 \%$ of parents believed their child's school should get parents' input about what should be taught in tobacco prevention programs; however, only $62 \%$ believed the school should train student leaders to help teachers present tobacco prevention lessons or give homework and projects about tobacco that involve families. It is quite evident that while parents would like to have input with regard to the design, content, and implementation of school-based tobacco prevention curricula and programs, they are not as eager to meaningfully contribute to this endeavor by becoming active participants in the process. Instead, it appears they would prefer to place this responsibility 
squarely on the teachers $(80.0 \%)$. Therefore, further education needs to be provided to parents in an effort to change their perceptions about the anti-tobacco effectiveness of student leader peer advocates and the importance of their own active involvement concerning the success of their child's tobacco prevention education.

Most of the comprehensive, highly effective tobacco prevention programs use peer leaders as part of their instructional strategy. By modeling social skills (Perry, Telch, Killen, Burke, \& Maccoby, 1983) and leading role rehearsals (Clarke, MacPherson, Holmes, \& Jones, 1986), peer leaders can help counteract social pressures on youth to use tobacco. In this manner and through the help of their peers, sixth-grade students may be able to receive the tobacco resistance skills that will empower them to become critical of the tobacco industry's marketing efforts and question the motives of those who encourage them to use tobacco. Research has demonstrated that school-based, tobacco-free social peer networks, activities, and campaigns against tobacco companies, have the potential to help adolescent students avoid or modify their tobacco use behaviors (Tobler, \& Stratton, 1997).

Additionally, it is widely reported in the literature that being a supportive parent and getting actively involved in the lives of one's children can provide a protective effect against smoking (Fleming, Kim, Harachi, \& Catalano, 2002; Mayhew, Flay, \& Mott, 2000). On the other hand, it has also been demonstrated that parent's indifference to their child's potential smoking habits increased the likelihood of smoking among 13-14 year olds (Dusenbury et al., 1992; Newman, \& Ward, 1989; Sargent \& Dalton, 2001).

Furthermore, findings in a recent study contrast the widespread notion that there is little parents can do to prevent their adolescents from becoming smokers (Sargent \& Dalton, 2001). After controlling for confounding influences, the researchers detected that adolescents who perceived strong parental disapproval of their smoking were less than half as likely to smoke compared with those who did not perceive strong parental disapproval. Moreover, nonsmoker teens who perceived strong disapproval in both parents at baseline were less than half as likely to become established smokers. By comparison, those teens who perceived their parents becoming more lenient and indifferent over time with regard to their smoking habits were significantly more likely to progress to the level of established smokers.

Sargent and Dalton (2001) discovered that the effect of parental disapproval of smoking was even stronger and more robust than the effect of parental smoking. Surprisingly, the effect of parental disapproval was as strong for parents who smoked as it was for nonsmoking parents. An interaction analysis suggested that the peer smoking effect was attenuated when both parents strongly disapproved of smoking, suggesting that parent disapproval made adolescents more resistant to the influence of peer smoking. Therefore, parents can decrease their children's likelihood of smoking, if they get actively involved in their lives, serve as good role models by not using tobacco, and show their non-acceptance of tobacco use clearly and repeatedly (Jackson, Bee-Gates, \& Henriksen, 1994; Jackson, \& Henriksen, 1997; Sargent \& Dalton, 2001).

Lastly, SES was an important factor to consider regarding parental support of school sponsored smoking prevention activities for their sixthgrade children. The low SES group was significantly more likely than the middle and high SES groups to support school sponsored smoking prevention activities. Research has demonstrated that the lower the levels of parental SES, such as education, social class, and income, the higher the likelihood of smoking by their adolescent children (Isohanni, Moilanen, \& Rantakallio, 1991; Millar \& Hunter, 1990; Soteriades \& DiFranza, 2003). After reviewing 21 such prospective studies, Conrad, Flay, and Hill (1992) concluded that an inverse association between SES and adolescent smoking was supported by $76 \%$ of the studies. Therefore, it is possible that parents in the low SES category recognized that a problem exists with adolescent smoking in Juárez, Mexico; possibly even with their own children. Thus, 
these parents were more in favor of instituting school sponsored smoking prevention activities for their sixth-grade children.

However, it is interesting to note that the one and only smoking prevention item in which low SES parents $(56.1 \%)$ were significantly less likely to be supportive of than their middle (63.2\%) and high SES (66.9\%) counterparts was the one pertaining to whether they believed their child's school should give homework and projects about tobacco that involve families (Appendix C).This lack of interest and apparent unwillingness of low SES parents to become actively engaged in their children's anti-tobacco education represents a vulnerability which the tobacco industry has fully exploited (American Heart Association, 2006) and subsequently, posses a potential threat to the health and wellbeing of young students.

Finally, a variety of limitations to this study should be noted. It is possible that the monothematic nature of the survey may have sensitized some parents to the research issues, resulting in a response-set bias in some, which could potentially threaten the internal validity of the findings. Moreover, the survey response rate was only $77 \%$, and while this represents a satisfactory rate for a mail home survey, it still posses a potential threat to the internal validity in light of the fact that the non-respondent parents may have had different perceptions than the ones presented by the parents who responded.

Additionally, since the survey was a crosssectional study of parental beliefs and perceptions, no cause and effect relationship can be drawn from the study results. The instrument did not discriminate between those who were supportive and not supportive of tobacco prevention activities, therefore other items not measured by the current questionnaire may have been more important to include on the survey. The study was limited to the parents of sixth grade students who attended randomly selected public and private middle schools in Juárez, Mexico. As a result, the participant parents may not be representative of all parents of students in this age group. This may have resulted in limited external validity of the study findings.

Lastly, well-designed school-based smoking prevention activities and programs are key to preventing the onset of smoking in school-aged adolescents and in turn were important to parent respondents in this study. The middle school setting may represent the most favorable frontier in the timely implementation of school-based tobacco prevention programs in the battle to limit or stave off early initiation of smoking among young students. School-based tobacco prevention programs have proven to be the most cost-effective and accessible programs that specifically target youth (Tobbler and Stratton, 1997) and in the present study, the majority of the participating parents in Juárez, Mexico appeared to be fully cognizant and quite supportive of such activities (88\%).

However, even though $79 \%$ of parent respondents believed their child's school should get parental input about what should be taught in tobacco prevention programs; disappointingly, only $62 \%$ felt that such activities should include homework and projects involving families. These results provide further evidence that if school-based adolescent tobacco prevention programs are to be successful, public health initiatives need to do a much better job not only soliciting and receiving parental input with regard to the anti-tobacco curricula but also in convincing parents of the importance of becoming active participants in the process.

\section{References}

American Heart Association. (2006). Tobacco industry's targeting of youth, minorities and women. Retrieved May 11, 2006, from http://www.americanheart.org/presenter. jhtml?identifier $=11226$

Bird, Y., Moraros, J., Olsen K. L., Forester-Cox, S., Staines-Orosco, H., (2006). Smoking practices, risk perception of smoking and environmental tobacco smoke exposure among adolescents in Ciudad Juárez, Mexico. Nicotine \& Tobacco Research, 8, 859-870. 
Centers for Disease Control and Prevention. (1994). Guidelines for school health programs to prevent tobacco use and addiction. MMWR, 43(RR-2), 1-18.

Centers for Disease Control and Prevention. (1996). Projected smoking-related deaths among youthUnited States. MMWR, 45, 971-974.

Centers for Disease Control and Prevention. (2001). SHPPS 2000: the school health policies and programs study. The Journal of School Health, 71, 249-350.

Clark, P., Scarisbrick-Hauser, A., Gautam, S. P., \& Wirk, S. J. (1999). Anti-tobacco socialization in homes of African-American and white parents, and smoking and nonsmoking parents. Journal of Adolescent Health, 24, 329-339.

Clarke, J., MacPherson, B., Holmes, D., \& Jones, R. (1986). Reducing adolescent smoking: a comparison of peer-led, teacher-led and expert interventions. The Journal of School Health, 56, 102-106.

Conrad, K. M., Flay, B. R., \& Hill, D. (1992). Why children start smoking cigarettes: Predictors of onset. British Journal of Addiction, 87, 1711-1724.

DiFranza, J. R., Rigotti, N. A., \& McNeill, A. D. (2000). Initial symptoms of nicotine dependence in adolescents. Tobacco Control, 9, 313-319.

Dusenbury, L., Kerner, J. F., Baker, E., Botvin, G., James-Ortiz, S., \& Zauber, A. (1992). Predictors of smoking prevalence among New York Latino Youth. American Journal of Public Health, 82, 5558.

Everett, S., Warren, C., Sharpe, D., Kann, L., Husten, C. G., \& Crossett, L. (1999). Initiation of cigarette smoking and subsequent smoking behavior among U. S. high school students. Preventive Medicine, 29, 327-333.

Fleming, C., Kim, H., Harachi, T., \& Catalano, R. (2002). Family processes for children in early elementary school as predictors of smoking initiation. Journal of Adolescent Health, 30, 184-189.

Flint, A., Yamada, E., \& Novotny, T. (1998). Black-white differences in cigarette smoking uptake: progression from adolescent experimentation to regular use. Preventive Medicine, 27, 358-364.

Glynn, T. (1989). Essential elements of school-based smoking prevention programs. The Journal of School Health, 59, 181-188.

Glynn, T. J., \& Manley, M. W. (1992). How to help your patients stop smoking. National Cancer Institute, NIH Publication No. 92-3064.

Instituto Nacional de Estadística Geografía e Informática. (2000). XII Censo de Población y Vivienda 2000. Cuaderno Estadístico Municipal, Ciudad Juárez Chihuahua. Aguascalientes, Aguascalientes: INEGI; 2000.

Isohanni, M., Moilanen, I., \& Rantakallio, P. (1991). Determinants of teenage smoking, with special reference to non-standard family background. British Journal of Addiction, 86, 391-398.

Jackson, C., Bee-Gates, D. J., \& Henriksen, L. (1994). Authoritative parenting, child competencies, and initiation of cigarette smoking. Health Education Quarterly, 21, 103-116.

Jackson, C., \& Henriksen, L. (1997). Do as I say: Parent smoking, antismoking socialization, and smoking onset among children. Addictive Behaviors, 22, 107-114.

King, K., Pealer, L., \& Bernard, A. (2001). Increasing response rates to mail questionnaires: a review of inducement strategies. American Journal of Health Education, 32, 4-15.

Mayhew, K., Flay, B., \& Mott, J. (2000). Stages in the development of adolescent smoking. Drug and Alcohol Dependence, 59(Suppl 1), S61-81.

Mexican National Addiction Survey. (1988). Secretaria de Salud, Direccion General de Epidemiologia. Encuesta Nacional de Addiciones, 1988 (ENA-88). México, D.F.:SSA. 1988;3:120-168.

Mexican National Addiction Survey. (1998). Secretaria de Salud, Direccion General de Epidemiologia. Encuesta Nacional de Addiciones, 1998 (ENA-98). México, D.F.:SSA. 1998;4:145-188.

Millar, W. J., \& Hunter, L. (1990). The relationship between socioeconomic status and household smoking patterns in Canada. American Journal of Health Promotion, 5, 36-43.

National Cancer Institute. (1990). School programs to prevent smoking: the National Cancer Institute guide to strategies that succeed. Rockville MD: US Department of Health and Human Services; NIH 90-500. 
Newman, I. M., \& Ward, J. M. (1989). The influence of parental attitude and behavior on early adolescent cigarette smoking. Journal of School Health, 59, 150-152.

Perry, C., Telch, M., Killen, J., Burke, A., \& Maccoby, N. (1983). High school smoking prevention: The relative efficacy of varied treatments and instructors. Adolescence, 17, 561-566.

Peto, R., Lopez, A., Boreham, J., Thun, M., \& Heath, C. Jr. (1994). Mortality from smoking in developing countries 1950-2000: indirect estimates from national vital statistics. New York: Oxford University Press.

Sargent, J. D., \& Dalton, M. (2001). Does parental disapproval of smoking prevent adolescents from becoming established smokers? Pediatrics, 108, 1256-1262.

Soteriades, E. S., \& DiFranza, J. R. (2003). Parent's socioeconomic status, adolescents' disposable income, and adolescents' smoking status in Massachusetts. American Journal of Public Health, 93, 1155-1160.

Tobler, N. S., \& Stratton, H. H. (1997). Effectiveness of school-based drug prevention programs: A metaanalysis of the research. Journal of Primary Prevention, 18, 71-128.

U. S. Department of Health and Human Services. (1988). The health consequences of smoking: Nicotine addiction. A report from the Surgeon General. Atlanta, GA: Centers for Disease Control and Prevention. DHHS Publication No. (CDC) 88-8406.

Valdes-Salgado, R., Micher, J. M., Hernandez, L., Hernandez, M., \& Hernandez-Avila, M. (2002). Trends of tobacco use among new students at the Autonomous National University of Mexico, from 1989 to 1998. Salud Pública Mexicana, 44, 44-53.

\title{
Acknowledgments
}

Special thanks are due to Dr. Rafael Catano-Calatayud, Coordinator of the Medical-Surgeon program at UACJ, who helped design the introductory letter and on occasion personally contacted the district school superintendents and participating middle school principals in an effort to secure our access to the schools; Larry Olsen, Associate Dean, College of Health \& Social Services at NMSU, who serves as a great mentor and a public health inspirational model; and more importantly, to all the school superintendents, principals, teachers, parents, and students in Juárez, Mexico for their stanch support, invaluable assistance, and unprecedented cooperation in the study.

\author{
Author Information \\ Yelena Bird, M.D., M.P.H., Associate Professor \\ Department of Health Science, MSC 3HLS \\ College of Health \& Social Services \\ New Mexico State University \\ P. O. Box 30001 \\ Las Cruces, NM, 88003, USA \\ Ph.: 505-646-4309 \\ Fax.: 505-646-6166 \\ E-Mail: yelenabird@yahoo.com \\ John Moraros, M.D., M.P.H., CHES \\ Robert W. Buckingham, Dr.P.H. \\ New Mexico State University \\ Hugo Staines-Orozco, M.D. \\ Universidad Autonoma de Ciudad Juárez
}


Jeffrey E. Brandon, Ph.D., Dean

College of Health \& Social Services

New Mexico State University

* corresponding author 


\section{Appendix A}

\section{Characteristics of the Parental Respondent Population}

\begin{tabular}{|c|c|c|c|}
\hline Characteristics & $\mathbf{N}$ & (\%) & $\begin{array}{l}\text { Parental Smoking } \\
\text { Prevalence Rate }^{\mathrm{a}}\end{array}$ \\
\hline \multicolumn{4}{|l|}{ Parental gender } \\
\hline Male & 124 & $(31.8)$ & $51.6^{\mathrm{b}}$ \\
\hline Female & 266 & $(68.2)$ & 34.9 \\
\hline Total & 390 & $(100.0)$ & \\
\hline \multicolumn{4}{|l|}{ Parental age } \\
\hline $20-29$ & 52 & $(13.3)$ & 34.6 \\
\hline $30-39$ & 210 & $(53.8)$ & $47.1^{b}$ \\
\hline $40-49$ & 79 & $(20.3)$ & 26.6 \\
\hline $50-59$ & 41 & $(10.5)$ & 39.0 \\
\hline$>60$ & 8 & $(2.1)$ & 37.5 \\
\hline Total & 390 & $(100.0)$ & \\
\hline \multicolumn{4}{|l|}{ Parental relationship to child } \\
\hline Mother/step-mother & 176 & $(45.1)$ & 35.8 \\
\hline Father/step-father & 108 & $(27.7)$ & $51.9^{b}$ \\
\hline Aunt/Uncle & 7 & $(1.8)$ & 42.9 \\
\hline Grandparent & 96 & $(24.6)$ & 35.4 \\
\hline Guardian & 3 & $(0.8)$ & 33.3 \\
\hline Total & 390 & $(100.0)$ & \\
\hline \multicolumn{4}{|l|}{ Parental level of education } \\
\hline Less than high school & 209 & $(53.6)$ & $47.8^{\mathrm{b}}$ \\
\hline High school graduate & 86 & $(24.6)$ & 33.3 \\
\hline Some college & 43 & $(11.0)$ & 30.2 \\
\hline College graduate and beyond & 42 & $(10.8)$ & 28.6 \\
\hline Total & 390 & $(100.0)$ & \\
\hline \multicolumn{4}{|l|}{ School setting } \\
\hline Public & 213 & $(54.6)$ & $45.5^{\mathrm{b}}$ \\
\hline Private & 177 & $(45.4)$ & 33.9 \\
\hline Total & 390 & $(100.0)$ & \\
\hline \multicolumn{4}{|l|}{ Socioeconomic status $^{\mathrm{c}}$} \\
\hline$(<10,000$ Mexican pesos $)$ & 148 & $(37.9)$ & $53.4^{b}$ \\
\hline Middle $\quad(10,001-25,000$ Mexican pesos $)$ & 106 & $(27.2)$ & 37.7 \\
\hline High $\quad(>25,000$ Mexican pesos $)$ & 136 & $(34.9)$ & 27.9 \\
\hline Total & 136 & $(100.0)$ & \\
\hline
\end{tabular}

a Percentages represent number of parents endorsing "Yes" to the questions.

${ }^{\mathrm{b}}$ Correlation is significant at $\mathrm{p}<0.01$ level for $\chi 2$ tests comparing differences by socioeconomic status.

${ }^{\mathrm{c}}$ Correlation is significant at $\mathrm{p}<0.01$ level for $\chi 2$ tests comparing differences by school settings. 


\section{Appendix B}

\section{Parental Support of School Sponsored Smoking Prevention Activities for Their Sixth-Grade Children by SES and School Setting}

\begin{tabular}{|c|c|c|c|c|c|c|c|c|}
\hline \multirow[b]{2}{*}{ Outcome Variables } & \multicolumn{4}{|c|}{ Public School Setting } & \multicolumn{4}{|c|}{ Private School Setting } \\
\hline & $\begin{array}{c}\text { Low } \\
\text { SES } \\
(\mathrm{N}=\mathbf{8 4})\end{array}$ & $\begin{array}{l}\text { Middle } \\
\text { SES } \\
(\mathrm{N}=57)\end{array}$ & $\begin{array}{l}\text { High } \\
\text { SES } \\
(\mathrm{N}=72)\end{array}$ & $\begin{array}{c}\text { Total } \\
\text { (N=213) }\end{array}$ & $\begin{array}{c}\text { Low } \\
\text { SES } \\
(\mathrm{N}=64)\end{array}$ & $\begin{array}{l}\text { Middle } \\
\text { SES } \\
(\mathrm{N}=49)\end{array}$ & $\begin{array}{l}\text { High } \\
\text { SES } \\
(\mathrm{N}=64)\end{array}$ & $\begin{array}{c}\text { Total } \\
(\mathrm{N}=177)\end{array}$ \\
\hline & $\%^{a}$ & $\%^{a}$ & $\%^{a}$ & $\%^{a}$ & $\%^{a}$ & $\%^{a}$ & $\%^{a}$ & $\%^{a}$ \\
\hline $\begin{array}{l}\text { My child's school should teach } \\
\text { students that most young } \\
\text { people do not smoke }\end{array}$ & $94.0^{b}$ & 87.7 & 87.5 & 90.1 & 90.6 & 85.7 & 89.1 & 88.7 \\
\hline $\begin{array}{l}\text { My child's school should teach } \\
\text { students why young people } \\
\text { start smoking }\end{array}$ & 83.3 & 80.1 & 81.9 & 82.2 & 82.8 & 79.6 & 79.7 & 80.8 \\
\hline $\begin{array}{l}\text { My child's school should teach } \\
\text { about the harmful physical } \\
\text { effects of tobacco use }\end{array}$ & $96.0^{b}$ & 89.5 & 88.9 & 92.0 & $95.3^{b}$ & 89.8 & 85.9 & 90.4 \\
\hline $\begin{array}{l}\text { My child's school should teach } \\
\text { about the harmful social } \\
\text { effects of tobacco use }\end{array}$ & 86.9 & 84.2 & 84.7 & 85.4 & 87.5 & 85.7 & 84.4 & 85.9 \\
\hline $\begin{array}{l}\text { My child's school should teach } \\
\text { students how to avoid tobacco } \\
\text { use }\end{array}$ & $89.3^{b}$ & 82.4 & 83.3 & 85.4 & $90.6^{b}$ & 85.7 & 84.4 & 87.0 \\
\hline $\begin{array}{l}\text { My child's school should provide } \\
\text { classroom lessons to help } \\
\text { students refuse pro tobacco } \\
\text { messages and advertisements }\end{array}$ & $88.1^{b}$ & 78.9 & 80.6 & 83.1 & $89.0^{\mathrm{b}}$ & 81.6 & 82.8 & 84.7 \\
\hline $\begin{array}{l}\text { My child's school should train } \\
\text { teachers to teach tobacco } \\
\text { prevention lessons }\end{array}$ & $86.9^{b}$ & 78.9 & 73.6 & 80.3 & $84.4^{\mathrm{b}}$ & 77.5 & 76.6 & 79.7 \\
\hline $\begin{array}{l}\text { My child's school should train } \\
\text { student leaders to help health } \\
\text { teachers present tobacco } \\
\text { prevention lessons }\end{array}$ & $66.7^{b}$ & 61.4 & 61.1 & 63.4 & 64.1 & 61.2 & 56.3 & 60.5 \\
\hline $\begin{array}{l}\text { My child's school should get } \\
\text { parents' input about what } \\
\text { should be taught in tobacco } \\
\text { prevention programs }\end{array}$ & 78.6 & 71.9 & 80.6 & 77.5 & 79.7 & 75.5 & $84.4^{\mathrm{b}}$ & 80.2 \\
\hline $\begin{array}{l}\text { My child's school should give } \\
\text { homework and projects about } \\
\text { tobacco that involve families }\end{array}$ & $59.5^{b}$ & 66.7 & 69.4 & $64.8^{\mathrm{c}}$ & $51.6^{b}$ & 59.2 & 64.1 & 58.2 \\
\hline
\end{tabular}




\section{Appendix C}

Multiple Logistic Regression Analysis of Parental Support of School Sponsored Smoking Prevention Activities for their Sixth-Grade Children by Gender, School Setting and SES (Reference category adjusted odds ratio 1.00)

\begin{tabular}{|c|c|c|c|c|c|c|c|}
\hline & \multicolumn{7}{|c|}{ Independent Variables } \\
\hline & \multicolumn{2}{|c|}{ Gender } & \multicolumn{2}{|c|}{ School Setting } & \multicolumn{3}{|c|}{ Socioeconomic Status } \\
\hline $\begin{array}{c}\text { School-Sponsored Smoking } \\
\text { Prevention Activities }\end{array}$ & Male & Female & Private & Public & High & Medium & Low \\
\hline $\begin{array}{l}\text { My child's school should teach } \\
\text { students that most young people } \\
\text { do not smoke }\end{array}$ & 1.00 & $2.73^{*}$ & 1.00 & 1.02 & 1.00 & 0.98 & 1.25 \\
\hline $\begin{array}{l}\text { My child's school should teach } \\
\text { students why young people start } \\
\text { smoking }\end{array}$ & 1.00 & $1.96^{*}$ & 1.00 & 1.02 & 1.00 & 0.99 & 1.02 \\
\hline $\begin{array}{l}\text { My child's school should teach about } \\
\text { the harmful physical effects of } \\
\text { tobacco use }\end{array}$ & 1.00 & 1.18 & 1.00 & 1.03 & 1.00 & 1.02 & $1.35 * *$ \\
\hline $\begin{array}{l}\text { My child's school should teach about } \\
\text { the harmful social effects of } \\
\text { tobacco use }\end{array}$ & 1.00 & $2.14^{*}$ & 1.00 & 0.99 & 1.00 & 1.01 & 1.03 \\
\hline $\begin{array}{l}\text { My child's school should teach } \\
\text { students how to avoid tobacco } \\
\text { use }\end{array}$ & 1.00 & 1.26 & 1.00 & 0.98 & 1.00 & 1.00 & $1.38 * *$ \\
\hline $\begin{array}{l}\text { My child's school should provide } \\
\text { classroom lessons to help } \\
\text { students refuse pro tobacco } \\
\text { messages and advertisements }\end{array}$ & 1.00 & $2.56^{*}$ & 1.00 & 0.98 & 1.00 & 0.98 & $1.38 * *$ \\
\hline $\begin{array}{l}\text { My child's school should train } \\
\text { teachers to teach tobacco } \\
\text { prevention lessons }\end{array}$ & 1.00 & $1.34^{*}$ & 1.00 & 1.01 & 1.00 & 1.04 & $1.35 * *$ \\
\hline $\begin{array}{l}\text { My child's school should train } \\
\text { student leaders to help teachers } \\
\text { present tobacco prevention } \\
\text { lessons } \\
\end{array}$ & 1.00 & 1.15 & 1.00 & 1.05 & 1.00 & 1.04 & 1.11 \\
\hline $\begin{array}{l}\text { My child's school should get } \\
\text { parents' input about what should } \\
\text { be taught in tobacco prevention } \\
\text { programs }\end{array}$ & 1.00 & $2.64 *$ & 1.00 & 0.97 & 1.00 & $0.82 *$ & 0.97 \\
\hline $\begin{array}{l}\text { My child's school should give } \\
\text { homework and projects about } \\
\text { tobacco that involve families }\end{array}$ & 1.00 & $2.96^{*}$ & 1.00 & 1.11 & 1.00 & 1.05 & $0.74 * *$ \\
\hline
\end{tabular}

$* \mathrm{p}<0.01 ; * * \mathrm{p}<0.05$ 